\title{
GOOD OR BAD RANGELAND? HYBRID KNOWLEDGE, SCIENCE, AND LOCAL UNDERSTANDINGS OF VEGETATION DYNAMICS IN THE KALAHARI
}

\author{
D. S. G. THOMAS ${ }^{* \dagger}$ AND C. TWYMAN \\ Department of Geography, University of Sheffield, Sheffield S10 2TN, UK
}

Received 3 December 2002; Revised 24 July 2003; Accepted 25 January 2004

\begin{abstract}
Using data from field studies in the Kalahari rangelands of Southern Africa, the relationships between 'scientific' and 'land user' interpretations of land degradation and change in nonequilibrium savanna ecosystems are explored. Scientific and landuser views are often regarded as distinct, and even opposed, knowledges. We contest that a more constructive view can be taken through the concept of hybrid knowledge, whereby value is attached to both approaches and through which a more useful and meaningful assessment of environmental change, and its implications for development and natural resource use, can be made. We find that in both the southwestern and northwestern Kalahari, pastoralists have a complex understanding of the patchiness of ecosystem variability, and that they utilise elements of this patchiness of change, notably dimensions of bush encroachment and grass species change that have commonly been regarded as degradation in scientific understandings, within livestock management strategies, especially at times of environmental stress. We urge caution in the application of the term degradation, and a more widespread recognition of the multifaceted dimensions, including benefits, of change within the scientifically recognized variability of nonequilibrium rangelands. Copyright (C) 2004 John Wiley \& Sons, Ltd.
\end{abstract}

KEY WORDS: $\quad$ knowledge repertoires; hybrid knowledge; ecological change; land degradation; Kalahari; Southern Africa

\section{INTRODUCTION}

The perception that environmental change is occurring at accelerated rates due to human mismanagement of natural resources, in the form of 'land degradation' or 'desertification' is an important force driving development policy and interventions in the Kalahari region of southern Africa, and dryland Africa in general (Leach and Mearns, 1996; Mearns, 1996; Sullivan, 2000). Scientific expertise has been at the forefront of large-scale and local attempts to reduce or reverse the impact of desertification/degradation (e.g. Thomas 1993; Corell, 1999). More recently the importance of involving indigenous knowledge, and the people actually experiencing and being affected by desertification, in the decision-making process, has been acknowledged (Seely, 1998; Sullivan, 2000). However, scientific and local land-user views of change do not always tally, leading to conflicts in aid agendas and policy recommendation (Thomas and Middleton, 1994), and regional differences in policy uptake and impact (Twyman et al., 2004).

This paper explores differences in scientific and local land-user views of vegetation state and dynamics using case studies from the Kalahari region of Southern Africa. We argue that simply juxtaposing one form of 'knowledge' against another as a test of validity is unhelpful and does not enhance our understandings of complex dryland social and environmental systems. However, by accepting that all forms of 'knowledge' are hybrid, and

\footnotetext{
*Correspondence to: D. S. G. Thomas, Department of Geography, University of Sheffield, Sheffield S10 2TN, UK.

E-mail: d.s.thomas@shef.ac.uk

${ }^{\dagger}$ Present Address (From 1 August 2004): School of Geography and the Environment, University of Oxford, Mansfield Road, Oxford OXI 3 TB, UK.

E-mail: david.thomas@ouce.ox.ac.uk
} 
that one form of knowledge should not be privileged over another, we argue that this approach provides a relevant platform or framework for better understanding the dynamics of vegetation change in drylands, as well as enhancing our understanding of sustainability and the persistence of change within rangelands. To tackle this at an empirical level requires innovative and hybrid methodologies (Batterbury et al., 1997) designed specifically to capture these knowledge repertoires. We suggest two different approaches: one 'science' led; and the other 'landuser' led, giving comparable but different interpretations of vegetation dynamics in rangelands.

\section{KNOWLEDGE REPERTOIRES}

According to Purcell (1998), western knowledge implies a set of understandings that include scientific knowledge as something separate from indigenous knowledge. Scientific knowledge is recognized as subject to fundamental changes in approach or paradigm shifts (Kuhn, 1970). Scientific knowledge has at times been portrayed as universal, objective, testable, verifiable and replicable. Methodologies are designed to be rigorous and the scientific community 'knows' the difference between good and bad science. However, the very nature of paradigm shifts acknowledges that scientific 'truth' may not be universal (Kuhn, 1977), and more recent postmodern and poststructuralist approaches argue that the relationship between science, myth and knowledge is complex (Scoones, 1999) and often imbued with political meaning. 'Western science' is now often portrayed in the western media as fallible (in particular in Europe), having 'failed' western society in the wake of food crises, disease outbreaks and the uncertainty over developments such as genetically modified organisms (GMOs), yet it is still viewed as privileged or superior to local knowledge especially in many 'development' contexts (Mitchell, 1995).

Local knowledge within the 'development' context has variously been portrayed as part of a romantic past (Milton, 1996), a major obstacle to development (Blaikie et al., 1997), a panacea to environmental problems (Inglis, 1993), and as a critical component to locally driven development (Nygren, 1999). It is something that local people 'have' and is generally viewed as quite distinct from science or western thinking. Thus, local and scientific knowledges have often been seen in static opposition, two forms of discrete, bounded knowledge. However, these static oppositions of local versus universal knowledges need to be challenged. Local people do not live in isolation, knowledge develops through experimentation and experience, from working with extension officers, or talking to people with different experiences, etc. There is therefore a need to establish more diversified models of understanding hybrid knowledges (Nygren, 1999), especially within the context of natural-resource dependent communities within drylands.

\section{Hybrid Knowledges}

According to poststructuralists, all knowledges are socially constructed and the focus of enquiry should be on the processes that legitimize certain hierarchies of knowledge and power between local and global (scientific) knowledges (Nygren, 1999). Thus, the conventional representation of local knowledge as something in opposition to modern knowledge is problematic in that it does not allow for the recognition of diversity within different people's knowledge repertories and inherently privileges one form of knowledge over another. Local knowledge is often seen as location-specific (and therefore fixed and rigid) rather than place-based (and therefore more fluid and dynamic (Escobar, 2001). Less attention has been paid to the contested and hybrid character of such knowledges and to the idea that local people produce shared knowledge (Nygren, 1999). According to Forsyth (1996), a constructive route is one that attributes more power to local communities, to use local knowledge as the starting point in research, and to use western science as the means to extend these to wider areas for management. This is what he calls hybrid knowledge. Within this paper we take Forsyth's (1996) and Nygren's (1999) notions of hybrid knowledges and develop an understanding of both scientific and local land-user views of vegetation characteristics and values under the impact of livestock grazing in the Kalahari region of Southern Africa.

\section{Scientific Understandings of Rangelands}

The nature of Kalahari savanna ecosystems means that temporal and spatial variability are normal characteristics of vegetation at any moment in time. Two principal factors contribute to this variability: animals and climate. Such 
systems have been described as disequilibrial, or as nonequilibrium systems, with the recognition in the 1980s and 1990s of this trait often described as representing a paradigm shift in ecological thinking (e.g. Wu and Loucks, 1995).

The interactions between grazing and browsing animals and vegetation are complex in savanna systems (Walker, 1987). On the one hand, intense grazing can lead to excessive removal of the most palatable species, which are usually perennial grasses. This reduces ground cover, but ultimately opens the way for less palatable and faster establishing annual grasses to gain a foothold, and, in many situations in the Kalahari, for shrub and bush species to become dominant as a function of the greater percolation of water to their rooting depths that the removal of perennial grasses facilitates (e.g. Walker and Noy-Meir, 1982). On the other hand, just enough grazing pressure stimulates the growth of palatable species, and increases their biomass (Crawley, 1983) and nutrient content (Scholes, 1990). In unbounded, mobile grazing systems, as practised by pastoral nomadism and migrating wild ungulate populations, animals move through the savanna landscape grazing selectively. Unless sedentary livestock systems, which are increasing within the Kalahari (e.g. Perkins, 1996; Thomas et al., 2000) and other savanna systems, are managed intensively, there are limited opportunities for the natural regulation of grazing pressures, and 'overgrazing' may result, leading to changes in plant communities, as described above.

Grazing and climate affect the amount of ground cover and the ratio between different plant elements, for example, shrubs, perennial grasses, and annual grasses, at a range of spatial and temporal scales. Seasonal and interannual rainfall variability affects which species are senesced or actively growing at any location. Plants are opportunistic, with small-scale spatial differences reflecting factors that include local soil nutrient differences, soil depth, and water availability. At larger scales, the spottiness of dryland rainfall events contributes to biomass and plant growth. The elements of variability mean that vegetation does not progress through stages dominated by different plant classes or species towards an ultimate climax, but rather that dynamism, both 'up' in response to growth-favouring conditions and 'down' in response to negative factors such as moisture shortages, fire, and heavy grazing, are the norm. This 'state and transition' (Walker et al., 1981) or disequilibrium (Behnke et al., 1993) behaviour means that reductions in diversity and biomass are not necessarily an indication of the fragility of such systems, but of the strategies and adaptations to cope with less-favourable circumstances and to set store for the onset of more favourable conditions in the future.

Distinguishing natural variability from the enhanced levels of change that may result from pressures related to human actions, particularly through livestock systems, can create problems in the assessment of degradation. The duality of increased vegetationless areas (sacrifice zones) and areas experiencing bush encroachment is widely cited as the principal characteristic of Kalahari environmental degradation (e.g. Ringrose et al., 1990). In many parts of the Kalahari the distribution of sacrifice and bush encroached zones is related to the radial pattern of livestock pressures around boreholes (e.g. Perkins, 1996). This means that the extent of these zones is unlikely to increase over time unless either more systems become degraded, or new boreholes are instigated on existing grazing units, thereby increasing the number of points from which pressure originates. As long ago as 1971, a spacing of $8 \mathrm{~km}$ between boreholes, each supporting no more than 400 head of livestock, was recommended by Jarman and Butler (1971) as representing a sustainable level of sedentary livestock production in the Kalahari.

Bush-encroached zones can in theory decrease in extent, through the effects of natural fire or specific management practices that restore the ecological balance in favour of grasses, since associated changes (nutrient and water) in the soil resource of encroachment-affected areas are generally absent (Dougill et al., 1999). Thus environmental restoration, at least in theory, is attainable. Few examples presently exist of specific attempts to decrease the extent of the bush layer, though in the Mier area of the Northern Cape in South Africa, a communitybased bush-clearance and grass-replanting scheme has been assessed, on lands where cattle production is being replaced by integrated livelihoods involving wildlife (van Rooyen, 1998). Drought events may not appreciably reduce bush densities. Encroached areas may be relatively drought resistant (compared to grass-rich areas) due to networks of deeper-rooting shrubs, a view supported by interannual analyses of vegetation cover, using remotely sensed data and field studies, by Ringrose et al. (1990). Finally, it can be noted that human interference with wildlife populations and their areas of concentration means that they too can contribute to the enhanced spatial variability of Kalahari vegetation. 


\section{Rural Livelihoods, Natural Resource Use and Rangelands}

While scientific understandings of rangelands have to a certain extent developed with commercial livestock production as a key focus, much local knowledge has developed with livelihood security and viability as its focus (cf. Sporton et al., submitted; Twyman et al., 2004). These different foci frame how we understand and interpret different knowledge repertoires. There is a significant literature concerning livelihoods and natural resource use in the Kalahari dryland of central southern Africa. Three themes are dominant in this work: the role of traditional hunting and gathering amongst the San (e.g. Lee and Devore, 1968); the growth of livestock-based, particularly cattle, livelihoods in the region (e.g. Odell, 1980; White, 1993); and the impacts of the latter upon the former in the final quarter of the 20th century (Hitchcock, 1978, 1985; Jerve, 1982; Wily, 1994). A parallel literature has also developed considering the impact of these livelihood changes on the natural resource base, particularly upon savanna vegetation systems (e.g. Skarpe, 1991; Dougill et al., 1999) and large herbivore wildlife populations (e.g. Williamson and Williamson, 1985). Together these investigations create a picture of the Kalahari today as a system undergoing marked environmental and social changes due to the overwhelming dominance of cattle production. This picture does not capture, however, the spatial variability and complexity of current natural resource-based livelihoods in the region as a whole, nor the variable interpretation of 'changes' in the environmental system. For while cattle production does occur widely today, research identifies marked variability in the composition of natural-resource-based activities across the region due to: position along the dryland climate gradient in the Kalahari; different land histories during the colonial and post-colonial periods (Sporton and Twyman, 2002); and complex state-originated interventions (e.g. Twyman, 2001).

Over the last century the Kalahari rangelands have been used opportunistically, seasonally and permanently for a range of natural-resource-based livelihoods. These include: livestock production (cattle, goats and sheep, both for subsistence and commercial use); hunting (both subsistence and commercial); provision of fuelwood and building materials; production of edible and tradable foods from the veld; and as a site for living. Use of natural resources has changed over time and is highly variable for different groups (and people within these groups) varying daily, weekly, seasonally and between years. Recent research in the Kalahari has shown that reliance on a range of resources and a range of livelihood options is widespread for many natural-resource-dependent communities (Twyman, 2001), allowing risk to be spread and keeping livelihood options open as an insurance mechanism. This implies that the linkages between livelihood opportunities and resource availability are not simple, linear and direct, dictated solely by availability or abundance of a resource. Rather, the links between livelihood opportunities and resource availability and use in rangelands at specific locations are shaped by the history of resource relationships and local land-user understandings of the environment. Perceptions and definitions of what constitutes useful rangeland resources, or what is viewed as 'good or bad rangeland', therefore potentially differ according to the definitions, categorizations and expected resource utilities of the viewer, showing that such concepts are dynamic, changing and open to alternative hybrid interpretations.

\section{RANGELAND CHANGE: TOWARDS HYBRID KNOWLEDGES}

As part of the PANRUSA (Poverty, Policies and Natural Resource Use in Southern Africa) research project (http: www.shef.ac.uk/panrusa), scientific and land-user assessments of rangeland condition and change were made in areas of livestock farming in the southwest and northwest Kalahari (Figure 1). We describe the characteristics of the study areas next, before outlining the research findings and their interpretation.

\section{Southwestern Kalahari Study Area}

The southwest Kalahari is an arid area, comprising undulating and partially vegetated linear sand dunes and isolated pan depressions, with a number of major dry river valleys, notably the Nossob, Molopo and Kuruman, traversing the dunefield (Thomas, 2002). The area receives $150-250 \mathrm{~mm}$ of rainfall per year largely in the summer months, but with an inter-annual variability in excess of 50 per cent (Bhalotra, 1985) and a high propensity for 
drought. The area straddles the boundaries of southeast Namibia, northwest South Africa and southwest Botswana and has, since the late 19th century, been used for pastoralism, increasingly on demarcated and fenced farm areas, which has replaced, and displaced, more opportunistic hunting and gathering activities. The area also possesses a large national park, recently renamed as the Kgalagadi Transfrontier Park, since it straddles the border between South Africa and Botswana. The establishment of the park in the 1930s also led to the displacement of livelihoods and people, both pastoralists and hunter-gatherers.

PANRUSA investigations focused on the South African and Botswana sectors of this region, which have contrasting histories of pastoralism. The South African area, known as the Mier District, was divided into farm units for European farmers in the early 20th century. From the 1930s onwards the district largely became an area of allocated communal lands and leasehold farms for coloured people, with goats and sheep the main livestock types being farmed. The grazed lands in this area are regarded as heavily degraded by van Rooyen (1998), who noted the widespread removal, under grazing pressure, of palatable mixed-species perennial grasses, the development of active devegetated dune crests, and the widespread colonization of annual grass species on dunes and interdunes and the development of Rhigozum trichotomum bush thickets in the interdune areas. Attempts have been made to move away from small-stock dependency in the Meir towards game ranching on farms and hunting leases on communal lands. Today only 54 per cent of households own livestock and for most communal farmers, livestock now constitutes a secondary livelihood strategy.

In the Kgalagadi District of southwest Botswana, the growth of livestock production has been marked since the 1950s, with the grazed area of the district rising from $13000 \mathrm{~km}^{2}$ in 1950 to around $32000 \mathrm{~km}^{2}$ by 1990 (White, 1993), and the number of official boreholes increasing from eight (plus seven wells) in the entire district in 1955 to approximately 380 in 1990 (Thomas, 2004). In the late 1970s, older leasehold farms in the Molopo and Nossop valleys were supplemented by ten leasehold farms established under the Tribal Grazing Land Policy (TGLP), in this case primarily for karakul sheep production, which is well suited to dry conditions, rather than cattle as elsewhere in the country. With the decline in the karakul pelt market in the 1980s other small stock production, plus some sheep, is the mainstay of both leasehold and communal pastoralists in the area.

\section{Northwestern Kalahari Study Area}

The northwestern Kalahari borderlands of Namibia and Botswana are also largely sandy terrain, but extensive calcrete deposits underlie the sands and outcrop in pan depressions. The area is also traversed by the narrow, elevated, Ghanzi Ridge of metamorphosed pre-Cambrian sediments. This region receives on average more rainfall than the southwestern Kalahari but with a mean annual precipitation of 300-500 mm and inter-annual variability of 40 per cent or more, this is still a highly variable and drought-prone area. Cattle and small-stock production is common in this area, both in Namibia and Botswana.

In the Omaheke District of Namibia separate land allocations for white commercial farms and for Tswana and Herero Communal Areas existed from 1913 until being repealed upon Namibian independence in 1990. The formal subdivision of land by ethnic group has effectively meant that commercial and communal production have been distinct for almost a century, and also that opportunities to move livestock according to environmental variability and resource availability in Communal Areas were restricted. Today pressures on the Communal Areas remain high, although on the basis of a 'willing seller, willing buyer', former white farms are being purchased for the resettlement of groups from crowded areas. Although this area is in the headwaters of the Nossop and Aoub rivers, which may experience some ephemeral flow, commercial lands tend to border the channel systems so that pastoral activities in Communal Areas have long been reliant on borehole and well water, with access to these facilities determining the ability to utilise the surrounding rangeland. Three Communal Areas were investigated in the PANRUSA Project.

Commercial farms have also existed on the better-watered Ghanzi Ridge in Botswana since the late 19th century, but most of the region has until recently been available for seasonal opportunistic hunting and gathering and for livestock production using the traditional 'cattle post' system (Perkins, 1996). Formal fenced leasehold ranches were developed near Ncojane from the early 1970s onwards (Thomas et al., 2000), and within a few years were commonly regarded as severely degraded (White, 1993). Within the Ghanzi District as a whole the 1990s 
progressively saw both the creation of Wildlife Management Areas for traditional non-livestock-based livelihood practices (Twyman, 1998) and the division of communal lands into leasehold farms for livestock production. Overall, in this region, therefore, land and water access has increasingly become formalized, and pastoralism has become increasingly sedentarized around the boreholes that have been sunk on leasehold allocations.

\section{Vegetation: State and Interpretation}

In both the southwestern and northwestern Kalahari study areas, field-based vegetation assessments were made during February-March, July-August and November 2000 using two approaches: 'scientifically'; and in discussion with land users. The scientific assessments employed quadrat and line intercept methods to determine percentage ground cover and species composition at a range of locations within farming units or at set distances from 'pressure points' including villages and farm unit waterpoints. Land-user assessments of vegetation were carried out as part of the participatory research into livelihoods in the Kalahari undertaken within PANRUSA. 'Key informants', usually livestock owners, were identified and then engaged in interviews and field walks or drives in order to find out about their use and interpretation of the physical environment, the values (negative and positive) attached to different plant species in the context of livestock grazing and other uses of the natural environment.

Two different strategies were employed in this dual approach to assessing natural capital. In the southwest Kalahari, 'scientific' assessments of vegetation were first conducted at fixed points along vegetation transects radiating out from water points and villages. This approach follows that used in piosphere assessments (e.g. Perkins and Thomas, 1993, and others) of vegetation changes associated with the use of permanent water points by livestock in the Kalahari. At set distances from the water point or village centre, $30 \mathrm{~m}$ line-intercept transects were laid out and along each the percentage of bare ground and percentage of each plant species present was measured. At each distance from the water point, at least three line-intercept surveys were made in order to reduce random effects, with mean values then calculated from the measurements taken. Following these surveys, key informant discussions and field drives were held with the lessee of Welkom Farm in order to find out his views on the vegetation, vegetation change and the utility of different species on his farm. A similar set of discussions and a farm drive was also conducted with the lessee of the adjacent farm unit, on which vegetation surveys were not conducted.

In the northwest Kalahari a different research approach was taken on two leasehold farms, in Ghanzi District, Botswana, and on three communal livestock units across the international border in Omaheke, Namibia. In these livestock areas, 'key informant' research was conducted prior to the ecological surveys being carried out. Following these participatory activities, ecological surveys were conducted within areas that had been identified by the informants as having particular utility or having experienced recent changes in plant composition. The effect of this is that the vegetation assessments have two formats to them: 'science' preceding key informant data; and key informant data preceding 'science'. The impact of these differences is the key informant-guided ecological surveys have the potential to include areas with particular characteristics, especially at the patch scale, which otherwise may be omitted from more conventional scientific assessments.

\section{VEGETATION ASSESSMENTS: SOUTHWESTERN KALAHARI}

Vegetation transects were conducted on the lands radiating from two villages, Struizendam and Khawa, from the water point on the leasehold Welkom Farm, and between two communal water points, Hartebeest and Good Hope (Figure 1). The two villages exert multiple pressures on their surrounding natural resources, both in terms of the small stock owned by many village residents and through pressures for fuelwood. Welkom is a leasehold farm, which has been leased from the Botswana Government by the same farmer for 40 years. Hartebeest and Good Hope are two 'cattleposts', $7.5 \mathrm{~km}$ apart, that are privately owned by farmers whose main land units are located within the Nossob valley farms. Since their establishment in 1985 they have been used as seasonal grazing resources but in recent years livestock has been permanently based at the boreholes, under the management of paid 


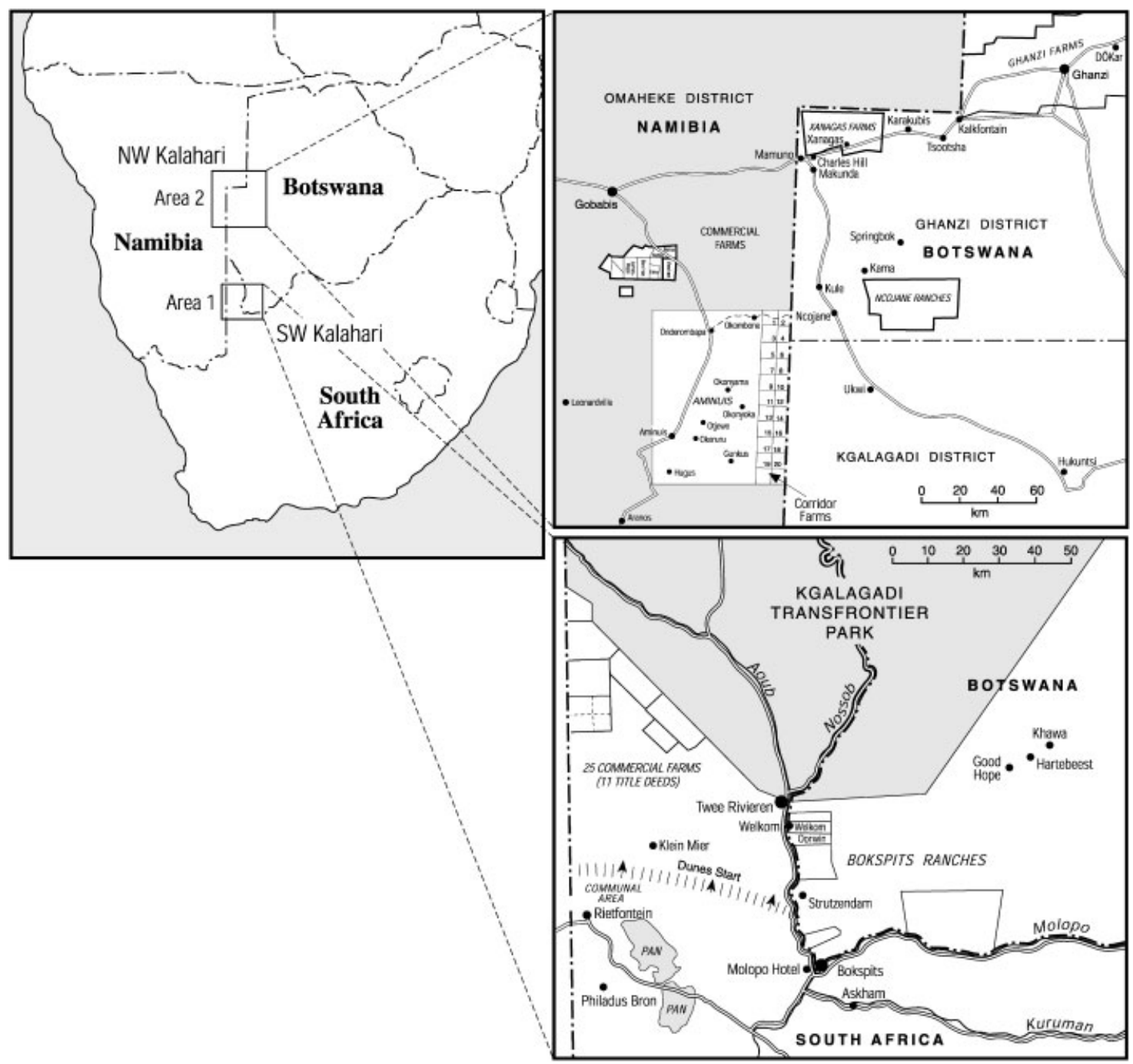

Figure 1. Map of the Kalahari, showing the location of study areas 1 and 2 and places mentioned in the text.

herders. Vegetation data were collected at the species level but have been grouped into five classes: trees and shrubs; annual grass species; palatable perennial grass species; hardy and disturbance-tolerant perennial grass species; and other plants (principally comprising creepers and species regarded as weeds). The perennial grasses, were grouped (Table I) according to the descriptions provided by van Oudtshoorn (1999) and van der Walt and le Riche (1999). At all locations where cover was measured, bare ground comprised 50 percent or more of all surfaces as a consequence of the combined effects of the natural adaptive strategies of arid-land plants to limited moisture availability and of land-use impacts. Figure $2 \mathrm{a}-\mathrm{d}$ shows, for each of the measurement distances at the four locations where these surveys were undertaken, the percentage of bare ground and the percentage of all vegetation represented by each vegetation group. This is preferred to simply showing vegetation classes as percentages of the ground surface due to the high percentage of bare ground at each location, which would have the effect of compressing vegetation class percentages together and masking real differences in vegetation composition at different sites. 
Table I. Plants identified in the southwest Botswana study area. Grazing utility of the grasses is according to van Oudshoorn (1999)

\begin{tabular}{|c|c|c|}
\hline Annual grasses: & $\begin{array}{l}\text { Sour grass } \\
\text { Nine-awned grass }\end{array}$ & $\begin{array}{l}\text { Schmidtia kalihariensis } \\
\text { Enneapogon cenchroides }\end{array}$ \\
\hline \multicolumn{3}{|l|}{ Perennial grasses: } \\
\hline \multirow[t]{4}{*}{ Palatable perennial grasses } & Gha grass & Centropodia glauca \\
\hline & Silky bushman's grass & Stipagrostis uniplumis \\
\hline & Tall bushman's grass & Stipagrostis ciliata \\
\hline & Short bushman's grass & Stipagrostis obtusa \\
\hline Hardy perennials, less grazing value & Kalahari dune grass & Stipagrostis amabilis \\
\hline \multirow{2}{*}{$\begin{array}{l}\text { Perennials that favour or tolerate disturbed } \\
\text { ground (various grazing values) }\end{array}$} & Lehmans love grass & Eragrostis lehmanniana \\
\hline & Nine awned grass & Enneapogon cenchroides \\
\hline \multicolumn{3}{|l|}{ Other small plants: } \\
\hline \multirow[t]{3}{*}{ Creepers } & Devils Claw & Harpagophytum procumbens \\
\hline & Eland's Pea & Senna italica \\
\hline & Gems Bean & Tylosema esculentum \\
\hline \multicolumn{3}{|l|}{ Opslag: } \\
\hline \multirow[t]{3}{*}{ (ephemerals and annuals) } & Wild everlasting & Helichrysum argyrosphaerum \\
\hline & Pretty lady & Cleome angustifolia \\
\hline & Acrotome & Acortome inflata \\
\hline \multirow[t]{6}{*}{ Shrubs: } & Driedoring & Rhigozum trichotomum \\
\hline & Broombush & Crotalaria spartioides \\
\hline & Jan bush & Gnidia polycephala \\
\hline & Good karoo & Pentzia incana \\
\hline & Kapok bush & Eriocephalus pubescens \\
\hline & Wild sage & Pechuel-loeschea leubnitziae \\
\hline \multirow[t]{7}{*}{ Trees: } & Camel thorn & Acacia erioloba \\
\hline & Grey camel thorn & Acacia haematoxylon \\
\hline & Candle thorn & Acacia hebeclada \\
\hline & Shepherds tree & Boscia albitrunca \\
\hline & Stink shepherds tree & Boscia foetida \\
\hline & Melifera & Acacia mellifera \\
\hline & Velvet raisin & Grewia flava \\
\hline
\end{tabular}

At Struizendam and Khawa bare ground is extensive within $5 \mathrm{~km}$ of the villages (Figure 2a and b), while levels are more consistent at Welkom Farm and between the Hartebeest and Good Hope cattle posts (Figure 2c and d). At almost all locations sampled, bare ground exceeds 40 per cent, and is often in excess of 60 per cent, figures well above the range recorded in the nearby Kgalagadi Transfrontier Park by Wiggs et al. (1994). Trees and shrubs represent up to 30 per cent of ground cover at $1 \mathrm{~km}$ distance from the two villages. In both cases Acacia mellifera is the dominant species, in thicket form. This species is a feature of bush encroachment in many parts of the Kalahari and is not highly valued as a species for either fuelwood or livestock browsing. At $10 \mathrm{~km}$ from the borehole at Welkom Farm the trees and shrubs value is also high. This location is close to the original borehole, and the present farmhouse, on the farm and is a sample point that represents an extensive area where interdunes are encroached on by a mixture of the shrub Rhigozum trichotomum and the annual grass Schmidtia kalahariensis. This area of the farm appears to be highly degraded, certainly in terms of the three characteristics (bare ground, $R$. trichotomum and S. kalahariensis) widely used as indicators of extensive degradation in the Meir District of South Africa (van Rooyen, 1998), a few kilometres to the west across the international border.

Schmidtia kalahariensis is a distinctive component of the vegetation at three locations. This species is a commonly used indicator of high land-use pressure, and is able to gain a foothold when palatable perennial grasses are impacted by high grazing pressures. Known as 'sour grass', S. kalahariensis is of relatively high nutritional value (van Oudtshoorn, 1999), though in its senesced dry-season form it is unpalatable and harmful to some grazers. It is notable that the Hartebeest-Good Hope transect is the only one where annual grasses represent a very 

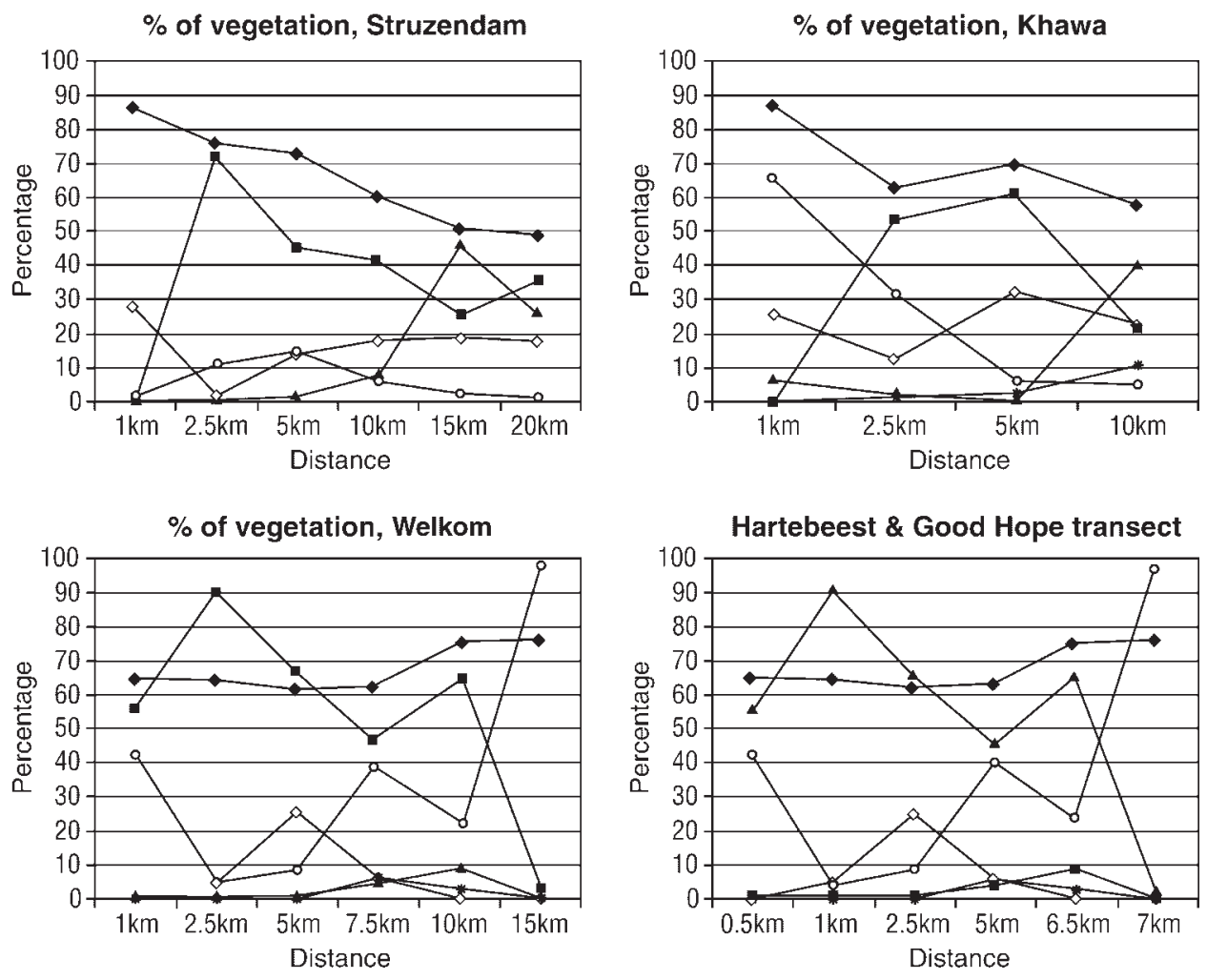

\begin{tabular}{ll|}
$\multimap-$ Trees and shrubs & $\rightarrow-$ Hardy and disturbed perennials \\
$\rightarrow$ Annual grasses & - Other plants \\
$\leftarrow$ Palatable perennials & - Bare ground \\
\hline
\end{tabular}

Figure 2. Vegetation classes according to distance from village or borehole. Percentage bare ground represents the total bare ground at each location; vegetation group percentages represent the percentage of all vegetation at that location.

small component of plant communities and where palatable perennial grasses are highly significant at all locations other than within $0.5 \mathrm{~km}$ of Hartebeest borehole, where a single weed species is prevalent. The abundance of palatable perennials may be a function of the status of these boreholes, until very recently, as seasonal grazing resources only, and the absence of all-year-round pressure on vegetation, particularly perennial grasses.

Overall the ecological surveys from southwest Botswana indicate that significant changes to ground cover and plant community composition have occurred through the impacts of livestock production. Key dimensions of grazinginduced changes include high levels of bare ground, bush encroachment around villages and on Welkom Farm and, with the exception of the lands between Hartebeest and Good Hope boreholes, the replacement of palatable perennial grasses with annual grasses dominated by S. kalahariensis. Bush encroachment, the loss of biodiversity associated with annual grass replacement of perennials, and the growth of bare ground are characteristics that in southern Africa, and the Kalahari in particular, are widely cited as major indicators of land degradation and desertification (e.g. de Queiroz, 1993; Perkins and Thomas, 1993), including in a study from the adjacent Meir District in South Africa (van Rooyen, 1998). What, however, are land-users assessments of these changes?

\section{Key Informant Assessments in the Southwest Kalahari}

To address this question field drives within the farm areas were arranged with the lessee of Welkom Farm and the lessee of the southerly adjacent farm, Oorwin. It did not prove possible to arrange equivalent investigations with livestock owners using the communal lands around the two villages. 


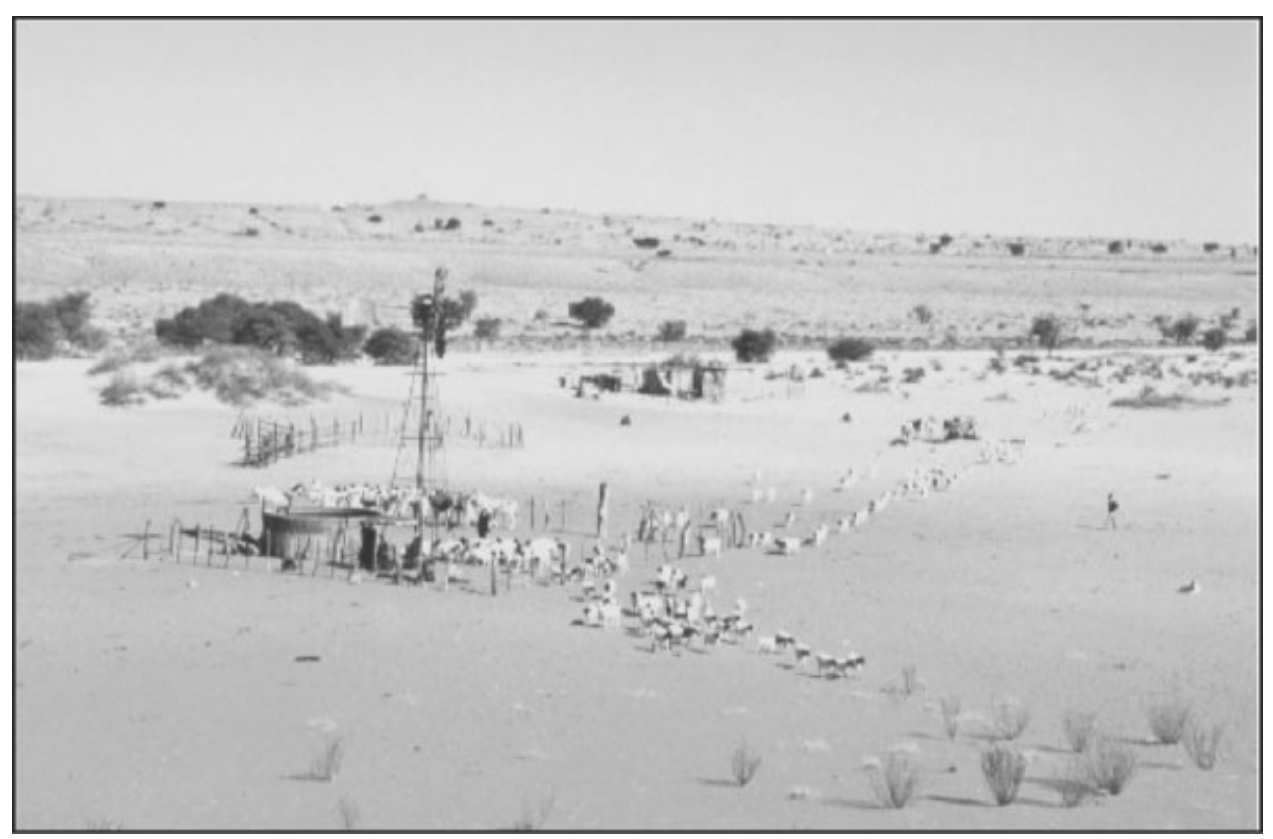

Figure 3. The main borehole water point on Welkom Farm. The photograph is taken in a southwesterly direction, from the top of a Kalahari dune ridge. Note the bare dune crest on the horizon, the bare area around the borehole, the beginning of an area of Rhigozum trichotomum in the right middle ground, and the extensive area between the borehole and the distant dune dominated by Schmidtia kalahariensis.

Welkom and Oorwin Farms both have perimeter fences and a number of internal paddocks, although, on Oorwin Farm in particular, paddock gates were usually found to be open. Welkom Farm currently supports 1000 livestock, mainly dorper sheep and goats together with about 30 cattle and a small number of karakul sheep. Up until the mid-1980s the farm had a single water point, close to the Nossop River valley and to the farmhouse. A new borehole was sunk $9 \mathrm{~km}$ to the east, and today this is the main focus of livestock production on the farm (Figure 3). Prior to the new borehole being sunk the dunes around the farm house had bare active crests, which created some problems, particularly in 1984-85, which was also a time of drought. Within four years of the new borehole being established the dunes near the house had stabilized and become colonized by vegetation, except in one area where today animals from the neighbouring farm encroach onto the dunes. The farmer noted that livestock prefer to move along the interdune areas but because the farms were aligned obliquely to the orientation of the dunes when they were established, animals have to move across the ridges to gain access to grazing, thereby contributing to dunecrest disturbance.

The farmer attached great significance to the areas of $R$. trichotomum on his land. Where it occurs on the calcareous soils that border the Nossob Valley, it acted as an important windbreak in the years when grazing pressures had denuded the grass cover. Furthermore, he viewed this bush as a vital and favoured fodder resource at a critical time of the year. $R$. trichotomum flowers profusely within two weeks of the first rains at the end of the dry season, with the flowers being a favoured food for sheep and goats. This he noted takes the pressure away from grasses allowing them to grow well in the early spring. The value attached to this shrub was also indicated in a discussion about the impact of bush fires. Whereas grasses take only one season to recover from major fires, such as one that occurred in the early 1980s, bushes may take up to six years, a period during which the browsing value of $R$. trichotomum flowers is lost. The most negative aspect of bushes that was cited was the tendency for lamb pelts and wool to be damaged when sheep enter bushy areas.

The large amounts of sour grass on the farm were regarded as a limitation on grazing, but the farmer did not feel that its extent was increasing. The farmer did identify patch-scale areas of mixed grass species, including the valuable Stipagrostis uniplumis (silky bushman's grass) and the highly prized gha grass (Centropodia glauca), 
both of which are valuable for grazing. However, he indicated that sour grass was also useful until it lies flat (i.e. senesces) in the dry season. He also said that while it was not the favoured grazing of animals when dry, livestock would gain a taste for it if molasses was initially added to a small patch to encourage them to eat it.

The lessee of Oorwin Farm is an elderly man who has been farming this land since the 1950s. At the time of this investigation he had 340 livestock of which 40 were cattle and the remainder were dorper sheep, breed and goats. He had had more animals in the past but felt that he was now too elderly to deal with larger numbers. He showed us the patchy distribution of different grass species on his land, indicating a detailed knowledge of the ecology of his farm. He noted that over the years sour grass had gained a foothold on the farm, and that the amount of bare dunes changed through time according to the rains. He too offered the information that $R$. trichotomum was a highly valued resource for livestock. He additionally noted that while grazing pressure would reduce grass species diversity, bare areas became important hosts of melons, which were extremely abundant in some areas of the farm. These were especially valuable for cattle, he noted, since not only did they provide abundant dry season food, but reduced the need for cattle to drink regularly.

\section{VEGETATION ASSESSMENTS: NORTHWESTERN KALAHARI}

Ecological investigations in this region were key-informant-focussed, with follow-up scientific assessments being conducted in locations highlighted by land users as of particular interest or importance for grazing activities. Three communal land areas in the Omeheke District, Namibia, and two leasehold farm units in Ghanzi District, Botswana, were the focus of ecological investigations (Figure 1). The locations in Namibia were Netso, a former European farm block allocated to Tswana groups in the 1980s; Okonyoka, a Herero settlement in the Aminuis Communal Area, and Corridor Four, which was previously a drought-emergency grazing area for European farmers but which has been progressively occuipied by Herero and Tswana households from the 1960s onwards.

When Tswana families first moved to Netso, the numbers of people and livestock were strictly regulated and pastoral activities were carried out on a rotational system promoted by the Ministry of Agriculture. Since 1992 more households have moved onto the farm block and rotational grazing has been largely abandoned. Like Netso, Corridor Four has a perimeter fence and has seen the number of households and livestock, principally cattle, increase, especially since Namibian independence. Until recently, Okonyoka was unfenced, being part of the Aminuis Communal Area, but high grazing pressures recently led the Community to initiate, without external assistance, the construction of a perimeter fence (Twyman et al., 2002). Nonetheless, livestock numbers at Okonyoka are high, with in excess of 2000 cattle and additional small stock owned by the residents of this community. In Ghanzi District, Botswana, informant-led investigations focused on the leasehold farm units of Springbok and Kama. Both are leased to livestock syndicates, and had boreholes drilled in 1997, though Springbok also has two older boreholes, dating from 1985 (now unproductive) and 1989. Both cattle posts are adjacent to fenced areas. Springbok is close to the fence around the government land of New Xganagas (a small service centre), while Kama is close to the perimeter fence of the Ncojane leasehold ranches. Though neither Springbok or Kama are themselves fenced, both syndicates are keen to erect one for the same reasons as the residents of Okonyoka-to keep out livestock from adjacent areas.

\section{Informant Assessments and Ecological Surveys, Omaheke Communal Lands}

Through the livelihood surveys of the PANRUSA Project, a key informant was identified who was willing to discuss livestock use and range conditions within each of the three communal-land study areas. Investigations comprised discussing the plants found in the area, where they were and what value they had in terms of livestock production. The movement and management of animals through the year and between wetter and drier periods were also discussed. Participatory maps were drawn, using aerial photographs as a further aid. Each key informant guided the mapping of areas with particular ecological conditions onto the map, sometimes assisted by other members of the community. Follow up drives were then undertaken, visiting the areas identified on the map. Subsequently, ecological assessments of each area were made to establish actual plant cover and species present. 
Figures 4 and 5 show the participatory maps and associated ecological data for Netso and Okonyoka. The maps show that land users have a detailed understanding of the distribution of the ecological resources within the lands that they use. At Netso, the key informant reported that there were many perennial grasses to be found and that rotational grazing was practiced on the key informant's part of the farm to ensure that resources were available for animals through both the wet and dry seasons. Perennial grasses were favoured as they retain a grazing value in the dry season, whereas annual grasses do not. The diversity of trees and shrubs was also noted and valued. Trees are important for goats while the seed pods of larger trees such as Acacia erioloba are a further dry-season resource, which can even be ground up and fed to animals to increase their nutritional value. Figure 5 shows summary species data from the ecological surveys conducted within the areas mapped by the informant. There is good accord between what was discussed and what was measured in the field.

Both Corridor Four and Okonyoka have low levels of ground cover in many areas, zones of dense bushes dominated by Acacia mellifera, which is widely regarded as a sign of poor range quality and extensive bush encroachment (e.g. White, 1993) and dominant swathes of sour grass (Schmidtia kalahariensis) (Figure 5), a legacy of intensive long-term grazing pressures, which have seen the widespread loss of perennial grasses. Key informants were aware of these changes but were also able to locate patches of better grasses with higher grazing values. Most interesting in these areas are the adaptations that livestock owners have made and are continuing to make in order to utilize the resources now available. As a whole, pastoralists in Okonyoka did not see the dominance of sour grass as a problem, and widely cited its value for grazing when young. Bush encroachment was also attached significant value, both by those who own goats, and as a resource during droughts when grasses fail. In Corridor Four, the key informant noted how in drought or towards the end of their dry season livestock are moved to areas of dense A. mellifera or Dichrostachys cinerea, to browse when other food sources are unavailable. A. mellifera stands were reported to have diminished significantly in recent years at Okonyoka, probably due to disease. Rather than viewing this as a positive diminishment of a species of low value, livestock owners noted how in the dry season they will now move their animals to Corridor farms where they have relatives in order to gain access to this resource. The key informant did suggest that since the perimeter fence had been erected and livestock from neighbouring areas excluded, there had been increases in perennial grasses, notably Stipagrostis uniplumis, in areas close to the boundaries of the land unit where pressures from Okonyoka livestock are lowest.

\section{Informant Assessments and Ecological Surveys, Ghanzi Leasehold Lands}

Simple farm maps were drawn with the informants at Springbok and Kama due to the unavailability of aerial photographs in the field to aid their production. Field walks and drives were carried out, with follow-up ecological surveys conducted within the ecological zones that were identified.

In 2000 Springbok supported 2000 cattle, 900 goats and 480 sheep, according to the lessees. Vegetation communities within the farm unit showed marked spatial heterogeneity (Table II), which the key informants identified as a function of the effect of different soils, and soil moisture. An extensive bushy area about $1 \mathrm{~km}$ from the boreholes was identified as being of particular value to the goats on the farm. A. mellifera is not common in this zone, which is dominated by Grewia flava and Commiphora africana. This bushy zone was not described as having increased in extent since grazing commenced on the lands, a comment which was also made with reference to the extensive zone of sour grass (S. kalahariensis) that extended from beyond the bush zone to a woody Terminalia sericea area close to the farm perimeter. The dominance of sour grass was not seen as a limitation on livestock production, in fact the informants noted that while it 'did not last as long' as perennial silky bushman grass, it was 'full of fat' and preferred by cattle. Several other grass species were identified by the informants, with some being noted as preferred grazing of different animals, including sheep and horses. The final area of note on the farm was a zone of calcareous soils that supported Dichrostachys cinerea, which is liked by goats and seen as an important dry-season and drought resource.

Although the syndicate that leased Kama Farm maintained only 100 cattle (noting that more may damage the vegetation) and had only held the unit since 1997, the farm borders the heavily grazed Ncojane Farm block to the south, which has been noted as an area of intense overgrazing (White, 1993). The Kama area possesses some dense A. mellifera thickets and mono-species areas of sour grass that may date from previous intense-grazing impacts, 


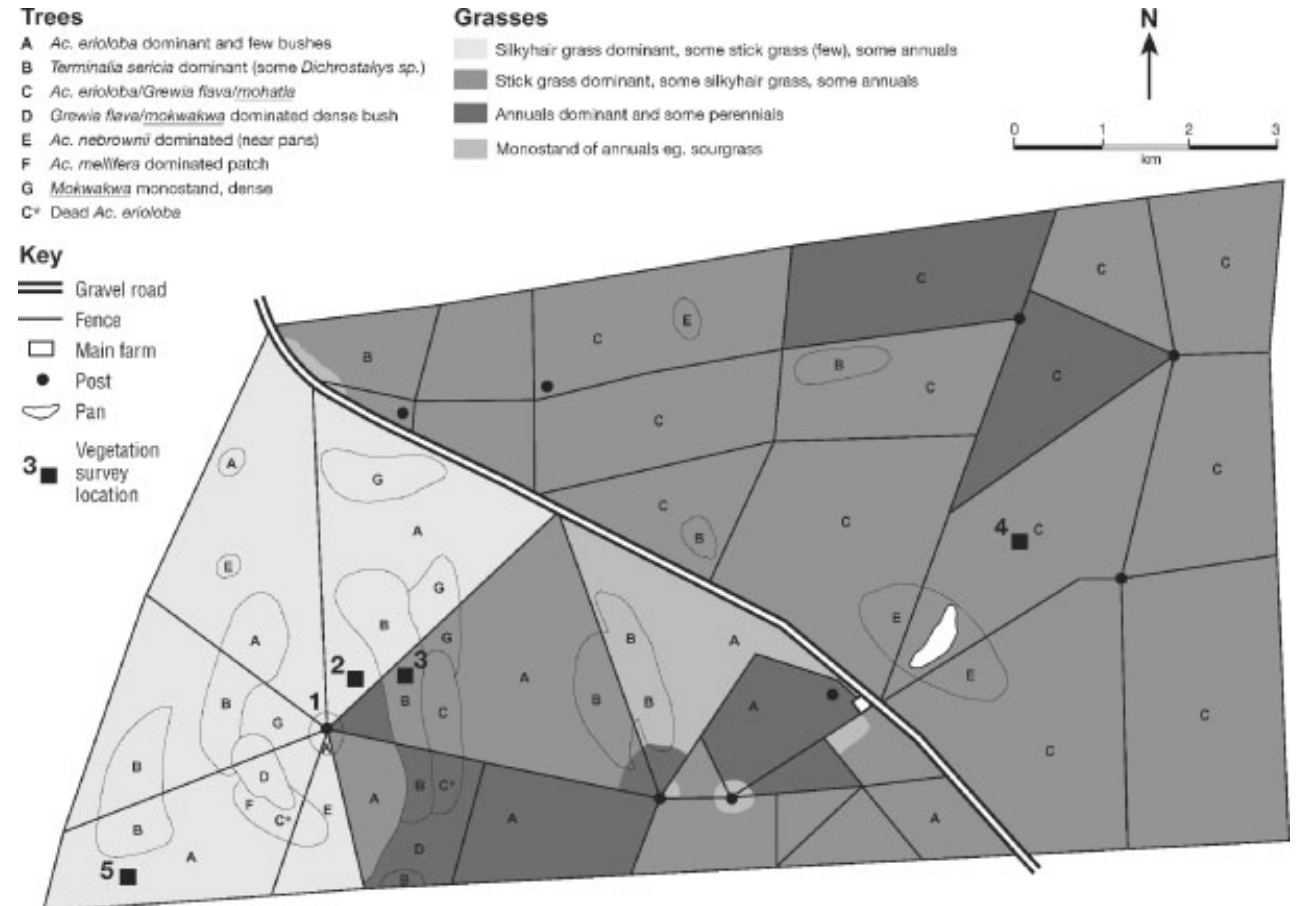

Ground cover at Netso

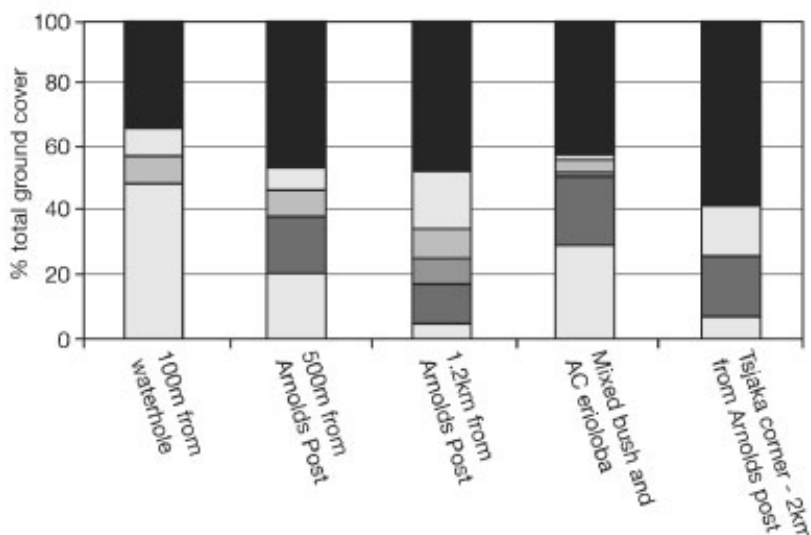

Bare ground

$\square$ Weeds

$\square$ Disturbed perennials

$\square$ Hardy perennials

Palatable perennials

$\square$ Annuals grasses

Trees and shrubs at Netso

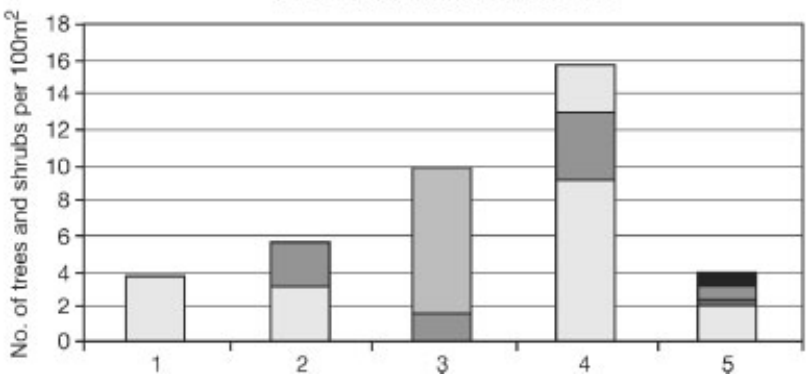

Acacia mellifera

$\square$ Mohathla

$\square$ terminalia sericea

$\square$ Grewia flava

Dichrostachys cinerea

$\square$ Acacia erioloba

Figure 4. Participatory vegetation maps and measured vegetation (a, ground cover; $b$, trees and shrubs) at Netso. 

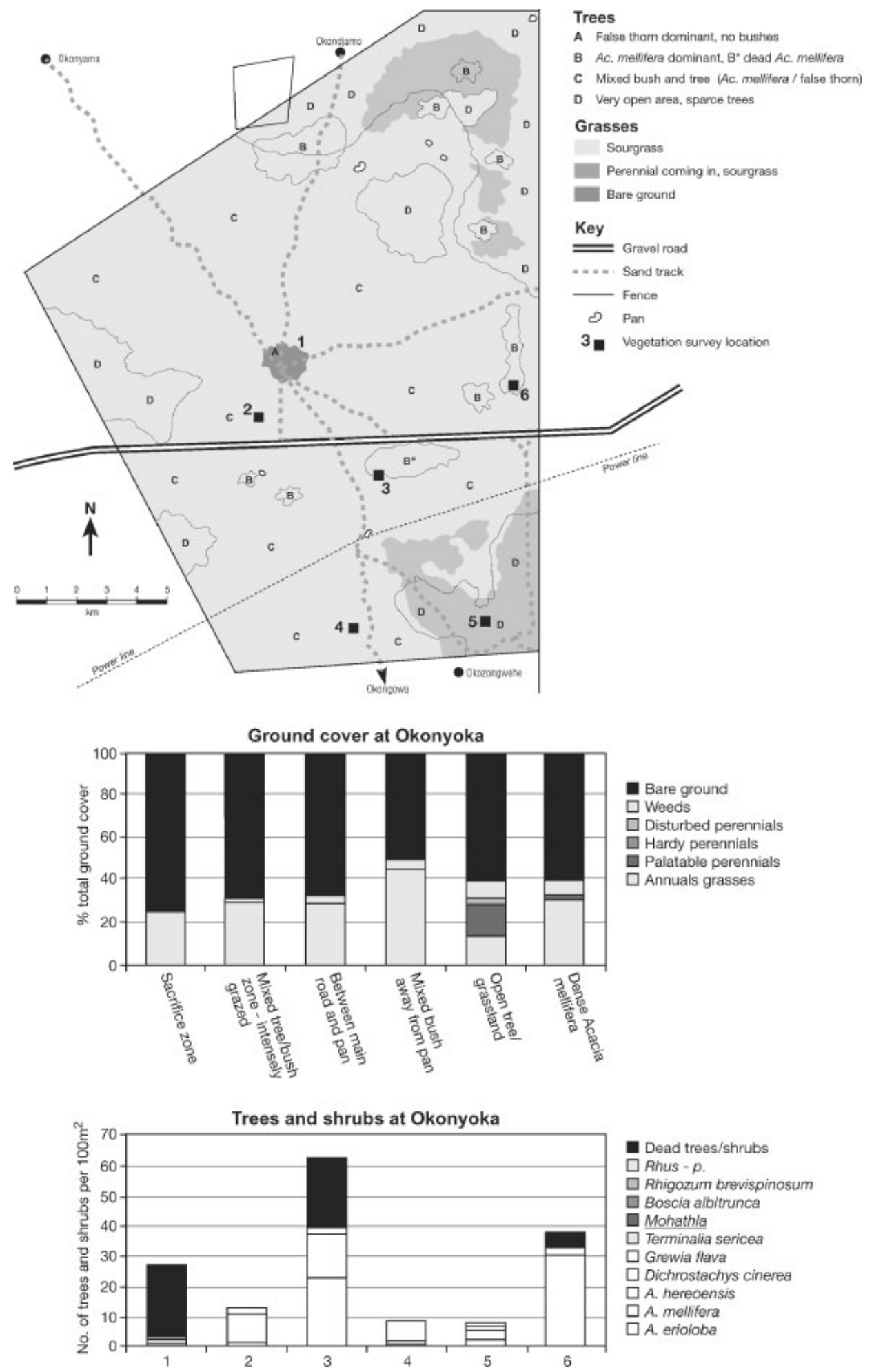

Figure 5. Participatory vegetation maps and measured vegetation (a, ground cover; b, trees and shrubs) at Okonyoka. 
Table II. Grasses identified within the northwest Kalahari study area

\begin{tabular}{lll}
\hline Annual grasses: & Sour grass & Schmidtia kalihariensis \\
& Nine-awned grass & Eneapogon cenchroides \\
Eragrostis viscosa & \\
Perennial grasses: & Sticky love grass & Stipagrostis uniplumis \\
Most palatable & Silky bushman's grass & Stipagrostis obtusa \\
& Short bushman's grass & Digitaria eriantha \\
& Sand quick & Panicum kalaharense \\
Hardy perennials, less grazing value & Finger grass & Eragrostis lehmanniana \\
& Kalahari buffalo grass & Eragrostis pallens \\
Perennials that favour or tolerate disturbed ground hirtigluma \\
(various grazing values) & Lehmans love grass & Aristida meridionalis \\
& Broom grass & Cyperus sp. \\
& Blue bushman grass & Eragrostis rigidior \\
& Giant three-awn grass & Various pan grasses and sedges \\
& Curly leaf & Eragrostis trichopora \\
& Black seed & Aristidia stipitata \\
& Stick grass & Melinis repens \\
& Red top & Aristida stipitata \\
\end{tabular}

since Kama appears to have been used as additional grazing by Ncojane farmers, who have previously been noted to drop their fences during droughts to allow livestock to graze more widely (Thomas et al., 2000). The informant at Kama indicated that the Ncojane farmers had rebuilt their dividing fence when asked to do so, but also noted that lessees of other farm units to the north were happy to let their animals stray onto the good grasses at Kama.

Kama had experienced two major fires in the 'last few years', one a few months prior to this study in November 2000. The farm drive indicated that, A. mellifera and S. kalahariensis areas apart, and despite the high levels of bare ground that result from the fire impacts, grass species diversity was high, with palatable perennial grasses, notably Stipagrostis uniplumis, representing between 30 percent and 65 percent of all grasses at sites where ecological surveys were conducted (Table II). The key informant noted the grazing value of the perennials, because of their persistence through the year if not over grazed. Sour grass was also noted as valuable and a favourite of livestock, although its limited longevity during the year in palatable form was noted as a limitation on its value.

\section{DISCUSSION AND CONCLUSION}

Biomass change is a complex dimension of land degradation. The simple interpretation of degradation that 'scientific' views have often attached to the occurrence of bush encroachment and grass species changes in the Kalahari can belie the complex interpretations and utilities that land users can attach to dimensions of these changes, as our case studies demonstrate. As well as our observations of adaptation and exploitations of change, Dougill et al. (1999) have indicated that there is evidence to suggest that pastoralists in the Kalahari can use specific elements of ecological changes as early warnings of possible more severe changes ahead. The view of dryland environments as variable and diverse means that conventional notions of 'overgrazing' and 'carrying capacity' are problematic as there is no 'normal' baseline ecological state from which to measure these concepts, a view clearly shared by land users involved in this research. Descriptions of areas on the verge of 'collapse' are the antithesis of a non-equilibrium perspective, which sees a wide range of variation as integral to the functioning of dryland ecosystems (Behnke et al., 1993). These new 'scientific' approaches therefore challenge conventional notions of rangeland change that have often underpinned land degradation and desertification policy. 
Few studies recognize the importance of scale in simultaneously assessing changes in both environment parameters and interpretations of those parameters across dryland regions. Our research suggests that land users are well aware of the spatial characteristics and dynamics of vegetation communities, and 'scientific' notions of states and transitions within non-equilibrium theory 'fit' with these understandings and explanations of changes within their rangelands.

Where change does occur, and change potentially occurs everywhere under non-equilibrium conditions, it is often not regarded as negative by indigenous land users. The findings in the southwestern Kalahari show that bush encroachment can provide new opportunities, as well as alternative strategies, for land and livestock management. In the northwestern Kalahari there is clear evidence that pastoralists exploit the spatial variability of the range in disequilibrium, both spatially and temporally at times of grazing stress.

Idealized 'scientific' notions of 'good or bad' rangeland reject the notion that changes in vegetation (such as bush encroachment) can be positive providing new opportunities for land and livestock management. Land users are clearly well aware of the spatial and temporal characteristics and dynamics of vegetation communities and are able to alter management practices accordingly. Land users are opportunistic and adaptive, and they are also strategic in their decision making, despite the often uncertain circumstances under which they have to manage their livelihoods.

Our findings show that by investigating knowledge repertoires we can provide a more useful and meaningful assessment of environmental change. Rather than seeking to test or verify one form of knowledge against another, we have used an innovative hybrid approach to empirically investigate these knowledge repertoires. By following both 'science' led and 'local land-user' led investigations we have provided a more nuanced account of 'change' within rangelands, and illustrated the hybrid character of both scientific and local land-user understandings of vegetation dynamics.

In conclusion we urge caution in the application of the term degradation within discourse of environmental, especially ecological, change in drylands, and a more widespread recognition of the multifaceted dimensions, including benefits, of change within the scientifically recognized variability of non-equilibrium rangelands.

\section{REFERENCES}

Batterbury S, Forsyth T, Thomson K. 1997. Transformations in developing countries: hybrid research and democratic policy. The Geographical Journal 163: 126-132.

Behnke RH, Scoones I, Kerven C (eds). 1993. Range ecology at disequilibrium. ODI: London.

Bhalotra YPR. 1985. Rainfall maps of Botswana. Department of Meteorological Services: Gaborone.

Blaikie P, Brown K, Stoking M, Tang L, Dixon P, Sillitoe P. 1997. Knowledge in action: local knowledge as a development resource and barriers to its incorporation in natural resource research and development. Agricultural Systems 55: 217-237.

Corell E. 1999. Non-state actor influence in the negotiations of the convention to combat desertification. International Negotiation 4: 197-223. Crawley MJ (ed.). 1983. The dynamics of animal-plant interactions. Blackwell: London.

de Querioz JD. 1993. Range degradation in Botswana: myth or reality? Pastoral Development Network Paper 35b. ODI: London.

Dougill AJ, Thomas DSG, Heathwaite AL. 1999. Environmental change in the Kalahari: integrated land degradation studies for non equilibrium dryland environments. Annals of the Association of American Geographers 89: 420-422.

Escobar A. 2001. Culture sits in places: reflections on globalism and subaltern strategies of localisation. Political Geography 20: $139-174$.

Forsyth T. 1996. Science, myth and knowledge: testing Himalayan environmental degradation in Thailand. Geoforum 27: 375-392.

Hitchcock RK. 1978. Kalahari cattleposts: A regional study of hunter-gatherers, pastoralists and agriculturalists in the western sandveld region, Central District, Botswana. Government Printer: Gaborone.

Hitchcock RK. 1985. Water, land and livestock: the evolution of Tenure and administrative patterns in the grazing area of Botswana. In The evolution of modern Botswana, Pickard L (ed.). University of Nebraska Press, NB: Lincoln; 84-121.

Inglis JT (ed.). 1993. Traditional ecological knowledge: Concepts and cases. International Programme on Traditional Ecological Knowledge and the International Development Research Centre: Canada.

Jarman TRW, Butler KE. 1971. Livestock management and production in the Kalhari. Botswana Notes and Records, Special Edition 1: 132139.

Jerve AM. 1982. Cattle and inequality. A study in rural differentiation from southern Kgalagadi in Botswana. DERAP Publications 143. Christian Michelson Institute: Bergen, Norway.

Kuhn TS. 1970. The structure of scientific revolutions, 2nd edn. Chicago University Press: Chicago, IL.

Kuhn TS. 1977. Second thoughts on paradims. In The Structure of Scientific Theories, Suppe F (ed.). University of Illinois Press: Urbana, IL; 459-482. 
Leach M, Mearns R. 1996. The Lie of the Land: Challenging received wisdom on the African environment. James Currey: Oxford.

Lee RB, Devore I (eds). 1968. Man the Hunter. Aldine: Chicago, IL.

Mearns R. 1996. Community, collective action and common grazing: the case of post-socialist Mongolia. Journal of Development Studies 32: 297-339.

Milton K. 1996. Environmentalism and cultural theory: Exploring the role of anthropology in environmental discourse. Routledge: London.

Mitchell T. 1995. The object of development: America's Egypt. In The power of development, Crush J (ed.). Routledge: London; $129-257$.

Nygren A. 1999. Local knowledge in the environment-development discourse. Critique of Anthropology 19: 267-288.

Odell ML. 1980. Botswana's first livestock development project: An experiment in agricultural transformation. Synergy International: Massachusetts.

Perkins JS. 1996. Botswana: fencing out the equity issue. Cattleposts and cattle ranching in the Kalahari Desert. Journal of Arid Environments 33: 503-518.

Perkins JS, Thomas DSG. 1993. Spreading deserts or spatially confined environmental impacts? Land degradation and cattle ranching in the Kalahari desert of Botswana. Land Degradation \& Rehabilitation 4: 179-194.

Purcell TW. 1998. Indigenous knowledge and applied anthropology: questions of definition and direction. Human Organisation 57: $258-272$.

Ringrose S, Matheson W, Tempest F, Boyle T. 1990. The development and causes of range degradation features in southeast Botswana using multi-temporal Landsat MSS imagery. Photogrammetric Engineering and Remote Sensing 56: 1252-1262.

Scholes RJ. 1990. The influence of soil fertility on the ecology of dry savannas. Journal of Biogeography 17: 415-419.

Scoones I. 1999. What prospects for a fruitful engagement? Annual Review of Anthropology 28: 479-507.

Seely M. 1998. Can science and community action connect to combat desertification? Journal of Arid Environments 39: 267-277.

Skarpe K. 1991. Impact of grazing on savanna ecosystems. Ambio 20: 351-356.

Sporton D, Twyman C. 2002. Politics, policy and livelihoods. In Sustainable Livelihoods in Kalahari Environments, Sporton D, Thomas DSG (eds). Oxford University Press: Oxford; 39-66.

Sporton D, Thomas DS, Twyman C. Submitted. Policy, poverty and livelihood 'security': implications for 'sustainable' natural resource based livelihoods in southern African drylands. Political Geography, 2003 (Special Issue).

Sullivan S. 2000. Getting the science right, or introducing the science in the first place? Local 'facts, global discourse- 'desertification' in north-west Namibia. In Political ecology: Science, myth and power, Stott P, Sullivan S (eds). Arnold: London.

Thomas DSG. 1993. Sandstorm in a teacup: understanding desertification in the 1990s. The Geographical Journal 159: 318-331.

Thomas DSG. 2002. Sand, grass, thorns, and ... cattle: the modern Kalahari environment. In Sustainable Livelihoods in Kalahari Environments, Sporton D, Thomas DSG (eds). Oxford University Press: Oxford; 21-38.

Thomas DSG. 2004. The environmental impact of groundwater exploitation in African grasslands. In Water resources in Drylands, Alsharan A, Wood WW (eds). Elsevier: Rotterdam. In press.

Thomas DSG, Middleton NJ. 1994. Desertification: Exploding the myth. Wiley: Chichester.

Thomas DSG, Sporton D, Perkins J. 2000. The environmental impact of livestock ranches in the Kalahari, Botswana: natural resource use, ecological change and human response in a dynamic dryland system. Land Degradation \& Development 11.

Twyman C. 1998. Rethinking community resource management: managing resources or managing people in western Botswana? Third World Quarterly 19: 745-770.

Twyman C. 2001. Natural resource use and livelihoods in Botswana's wildlife management areas. Applied Geography 21: 45-68.

Twyman C. 2000. Livelihood opportunity and diversity in Kalahari wildlife management areas, Botswana: rethinking community resource management. Journal of Southern African Studies 26: 783-806.

Twyman C, Dougill A, Sporton D, Thomas DSG. 2002. Community fencing in open rangelands: a case study of community self-empowerment in eastern Namibia. Review of African Political Economy 27: 9-26.

Twyman C, Sporton D, Thomas DSG. 2004. Where is the life in farming? The viability of smallholder farming on the margins of the Kalahari. Geoforum. 35: 69-85.

van der Walt P, le Riche E. 1999. The Kalahari and its plants. Unpublished manuscript: Pretoria.

van Oudtshoorn F. 1999. Guide to grasses of southern Africa. Briza: Pretoria.

van Rooyen AF. 1998. Combating desertification in the southern Kalahari: connecting science with community action in South Africa. Journal of Arid Environments 39: 285-298.

Walker BH (ed.). 1987. Determinants of Tropical Savanna. IRL Press: Oxford.

Walker BH, Noy-Meir I. 1982. Aspects of the stability and resilience of savanna ecosystems. In Ecology of tropical savannas, Huntley BJ, Walker BH (eds). Springer-Verlag: Berlin; 556-590.

Walker BH, Ludwig D, Holling CS, Pterman RS. 1981. Stability of semiarid savanna grazing systems. Journal of ecology 69: $473-498$.

White R. 1993. Livestock development and pastoral production on communal rangeland in Botswana. The Botswana Society: Gaborone.

Wiggs GFS, Thomas DSG, Bullard JE, Livingstone I. 1994. Dune mobility and vegetation cover in the southwest Kalahari Desert. Earth Surface Processes and Landforms 21: 19-24.

Williamson D, Williamson J. 1985. Botswana's fences and the depletion of Kalahari wildlife. Parks 10: 5-7.

Wily E. 1994. Hunter-gatherers in Botswana and the land use issue. Indigenous Affairs 2: 6-19.

Wu J, Loucks OL. 1995. From balance of nature to hierarchical patch dynamics: a paradigm shift in ecology. The Quarterly Review of Biology 70: $439-466$. 